\title{
VILÉM FluSSER, UM FILÓSOFO DA \\ LINGUAGEM BRASILEIRO
}

\section{Debora Pazetto Ferreira ${ }^{I}$}

Resumo: O objetivo deste artigo é contribuir com o conhecimento e reconhecimento da filosofia brasileira, apresentando alguns aspectos da teoria de um de nossos autores mais originais, Vilém Flusser. Embora seja um pensador judeu de origem tcheca, Flusser foi naturalizado brasileiro e viveu mais de trinta anos em São Paulo. Nesse período, escreveu uma importante e pouco discutida parte de sua obra. Por esse motivo, pretendemos expor alguns aspectos da ontologia inicial de Flusser, que marcam sua permanência em solo intelectual brasileiro. $\mathrm{O}$ artigo concentra-se em sua tese inaugural de que a língua e a realidade são o mesmo, ou melhor, de que as diversas línguas se identificam com as diversas realidades - tese defendida em seu primeiro livro publicado, em 1963, Lingua e realidade.

Palavras-Chave: Filosofia brasileira. Língua. Realidade. Ontologia.

A filosofia no Brasil não é um assunto muito discutido fora e, geralmente, tampouco dentro dos círculos acadêmicos. Provavelmente, isso acontece porque a tradição filosófica valorizada sempre foi predominantemente europeia - mais recentemente, norte-americana - e porque nossa educaçáo acadêmica sempre enfatizou mais o estudo de determinadas questóes, em determinados autores, do que a elaboração de um pensamento próprio e original. Meu objetivo, neste artigo, é contribuir com o conhecimento e reconhecimento da filosofia brasileira, apresentando alguns aspectos teóricos de um de nossos autores mais originais, Vilém Flusser. Embora seja um pensador judeu, de origem tcheca, Flusser veio ao Brasil com apenas vinte anos de idade, no início da década de quarenta do século XX, refugiado do regime nazista, e viveu mais de trinta anos em São Paulo. Nesse período, escreveu uma importante e pouco discutida parte de sua obra. Sua formaçáo como pensador e escritor aconteceu no Brasil, no entanto, tornou-se um autor reconhecido, principalmente como um teórico dos media, apenas depois que voltou para a

${ }^{1}$ Professora de Filosofia e do Programa de Pós-Graduação em Educação Tecnológica do Centro Federal de Educação Tecnológica de Minas Gerais (Cefet-MG), Belo Horizonte, MG - Brasil. E-mail: deborapazetto@gmail.com

Doutora em Filosofia pela UFMG.

http://dx.doi.org/10.1590/0101-3173.2018.v41n2.03.p37 
Europa e publicou, em 1983, Filosofia da caixa preta, na Alemanha. A primeira fase de sua filosofia, desenvolvida e publicada no Brasil, continua sendo muito pouco estudada, em comparação com a fase europeia de sua obra. ${ }^{2}$ Por esse motivo, pretendemos expor alguns aspectos da ontologia inicial de Flusser, os quais marcam sua permanência em solo intelectual brasileiro e que são defendidos principalmente em seu primeiro livro publicado, em 1963, pela editora paulista Herder, Lingua e realidade.

Naturalizado brasileiro na década de cinquenta, o pensador - mesmo sendo autodidata e sem formação acadêmica - lecionou Filosofia no ITA, na Escola Politécnica da USP e assumiu uma cadeira de Ciências da Comunicação na Fundação Armando Álvares Penteado (FAAP). Na década de setenta, a reforma universitária direcionou todos os professores de Filosofia da USP ao Departamento de Filosofia da Faculdade de Filosofia, Letras e Ciências Humanas, e o pensador tcheco não teve seu contrato renovado, provavelmente devido à falta de comprovação de seus títulos acadêmicos. Não obstante, era extremamente popular, como professor, e seus alunos costumavam visitá-lo para discutir ideias no terraço de sua casa. Não apenas publicou mais de trinta livros - primeiro em português e, depois, num constante processo de autotradução, em diversas outras línguas - como escreveu centenas de artigos para revistas especializadas, como a Revista Brasileira de Filosofia e o Suplemento Literário, e jornais populares, como a Folha de S. Paulo e O Estado de S. Paulo. Flusser também mantinha contato íntimo com artistas e pensadores brasileiros: publicou diversos ensaios críticos sobre suas obras, conheceu pessoalmente ou manteve correspondência com vários desses intelectuais e dedicou, em sua autobiografia filosófica, onze capítulos dedicados a personalidades com as quais travou intenso diálogo, no período em que esteve no Brasil: os brasileiros Milton Vargas, Vicente Ferreira da Silva - o qual Flusser considera o melhor e talvez o único filósofo brasileiro -, João Guimarães Rosa, Miguel Reale, Haroldo de Campos, Dora Ferreira da Silva e José Bueno; e os imigrantes que conheceu no Brasil, Samson Flexor, Alex Bloch, Romy Fink e Mira Schendel.

\footnotetext{
${ }^{2}$ Há importantes referências bibliográficas que tratam das teorias desenvolvidas por Flusser, durante o período em que ele morou no Brasil, como A época brasileira de Vilém Flusser, de Eva Batlickova (2010), Vilém Flusser: a tradução na sociedade pós-histórica, de Claudia Santana Martins (2011), que dedica o primeiro capítulo a essa questâo, e ainda a coletânea organizada por Gustavo Bernardo Krause, Vilém Flusser no Brasil (2000). Ainda assim, e sobretudo em nível internacional, o período brasileiro do pensamento de Vilém Flusser é pouquíssimo estudado, em comparação com suas teorias publicadas em solo europeu. Este artigo se alinha com as tentativas anteriores de destacar a originalidade brasileira do pensamento de Flusser, focando em alguns conceitos específicos que serão desenvolvidos ao longo do texto.
} 
Uma das melhores maneiras de caracterizar o pensamento de Flusser é com o adjetivo "acolhedor": além de sua escrita livre cativar os leitores e acolhê-los na trama de suas ideias, qualquer assunto parece digno de suas consideraçôes: desde a ameba e a menopausa até os banheiros domésticos, como vemos nos manuscritos não publicados do Flusser Archive: tudo pode ser acolhido filosoficamente. Assim como o Vampyroteuthis infernalis - para usarmos sua metáfora, que intitula o livro escrito em parceria com o artista plástico Louis Bec - lança seus tentáculos em todas as direçóes, apalpando e assimilando qualquer saliência do seu abismo, Flusser deixa-se provocar e replicar filosoficamente pelos mais variados elementos de seu ambiente, a cultura ocidental. Contudo, por mais abrangente que seja sua obra, podemos identificar uma estrutura ontológica que se mantém praticamente inalterada como fundamento, mesmo em sua tão debatida teoria dos media. Prosseguindo com a metáfora vampyroteuthica: sua filosofia é polípode, mas tem apenas uma cabeça, a qual conecta os tentáculos e coordena seu direcionamento ao ambiente. Essa cabeça é a tese radical, elaborada no período brasileiro de sua filosofia, que afirma a identidade entre língua e realidade. A tese de que ser é o mesmo que poder ser expresso ou pensado não é inédita na tradição filosófica, pelo contrário, pode ser encontrada nos primórdios do pensamento grego. No poema de Parmênides, lemos que "o mesmo é o pensar e, portanto, ser" ou "nem conhecerias o que não é, pois não é realizável, nem o dirias." (PARMÊNIDES, 1999, p. 122). Também em Leibniz, Frege, Wittgenstein, Apel e Gadamer é possível apontar aproximaçóes com a ideia de que ser é poder ser expresso. Flusser radicaliza essa tese, a ponto de igualar a realidade à língua, ou melhor, as diversas realidades às diversas línguas. Não porque a realidade esteja "dentro" da língua, mas porque aparece exclusivamente em forma de língua.

Flusser afirma que é inerente à existência humana organizar as aparências caóticas, procurando uma estrutura que as articule, fixando-as em um sistema de referências hierarquizado. O caos é irreal, porque é algo a que não temos acesso, todavia, ele é realidade em potência, pois pode vir a ser cosmos. A estrutura que realiza o caos em cosmos é a língua: "O objetivo desse trabalho é contribuir para a tentativa de tornar consciente a estrutura desse cosmos restrito. Será proposta a afirmação de que essa estrutura se identifica com a língua." (FLUSSER, 2007, p. 33). A língua é um sistema simbólico que fixa as aparências em palavras e estabelece regras para coordená-las, permitindo o acesso às mesmas. Dito de outro modo, a língua cria a realidade, porque cria a apreensibilidade e a compreensibilidade. Simultaneamente, esse processo cria o ser humano como intelecto que apreende e compreende. Assim, o alicerce 
da ontologia de Flusser é a tese de que o desenvolvimento da língua é o próprio surgimento da realidade (aquilo que pode ser apreendido) e do intelecto humano (aquilo que apreende). Uma vez que a língua não é algo universal, o pensador conclui que a estrutura da realidade é relativa à estrutura das diferentes línguas (dentre as quais identifica três tipos básicos: flexionais, isolantes e aglutinantes). Cada língua tem sua própria ossatura ontológica, seu próprio sistema de categorias. $\mathrm{Na}$ teoria de Flusser, isso equivale a defender que há múltiplas realidades, tâo distintas entre si que intelectos flexionais, por exemplo, sequer poderiam vislumbrar como seria a realidade de um esquimó. Para fazê-lo, teriam que penetrar profundamente na vivência das línguas aglutinantes, abandonando momentaneamente a realidade ocidental familiar. A esse respeito, enfatizo que a língua portuguesa era extremamente valorizada pelo autor, por ser uma língua sem tradição filosófica e que, justamente por isso, seria mais plástica e flexível para o desenvolvimento de um pensamento sério, porém, criativo e livre da rigidez histórica da filosofia europeia.

É preciso advertir que quase todos os conceitos centrais de Flusser são utilizados em sentido dilatado, no entanto, em certos momentos, os mesmos termos aparecem em algum sentido mais restrito. Embora ele não esclareça devidamente essa questão, quando afirma que cada língua tem uma ontologia, por exemplo, a palavra "ontologia" é usada em sentido mais restrito do que quando ele sustenta uma "ontologia" que iguala língua à realidade, pois essa igualdade vale para qualquer língua, para qualquer realidade - trata-se de um princípio ontológico univoco que funda a pluralidade das ontologias linguísticas. Do mesmo modo, "língua", em sentido mais restrito, refere-se aos idiomas, com seus três caules principais e inúmeras ramificaçóes. Mas, em sentido dilatado, "língua" é um conceito muito abrangente, o qual inclui não apenas todos os idiomas vernáculos, mas também imagens, sons, ciência, pensamento, matemática, e assim por diante. Nesse sentido, conhecimento, arte, verdade, religião e filosofia são aspectos das línguas, logo, variam de acordo com a língua em que são - caso sejam - desenvolvidos.

Estamos diante de uma ontologia sui generis, capaz de sustentar que a realidade é nexo entre palavras, sem, todavia, comprometer-se com um nominalismo que concebe palavras como mero sopro da voz (flatus vocis), uma vez que a língua efetivamente gera efetividade. Fora da língua, há nada (de acessível e compreensível). Interpreto essa ideia em termos de imanência da existência humana - o que há para além dela é o vazio do inapreensível. "Realidade", evidentemente, significa "realidade para nós", humanos, que transformamos o caos em 
cosmos. A tese de que não podemos conhecer a realidade em si é rapidamente associável à filosofia crítica kantiana, isto é, à restrição da filosofia ao modo como conhecemos, pensamos e formamos os fenômenos. Contudo, para Flusser, não há um sujeito transcendental com formas a priori de conhecimento que filtram e configuram as coisas, de maneira que náo podemos ter acesso a uma suposta coisa em si. Sem a mediação de uma língua, o sujeito sequer se constituiria: "No íntimo sentimos que somos possuídos por ela [a língua], que não somos nós que a formulamos, mas que é ela que nos formula." (FLUSSER, 2007, p. 37). Não há qualquer a priori: nem as formas de conhecimento do sujeito, nem o mundo ou a coisa em si, porque tanto o intelecto quanto a realidade se formam na medida em que as línguas se formam. Não há mundo anterior à língua, não há sujeito anterior à língua e não há língua anterior à língua - há apenas desenvolvimentos, surgidos por acaso ou intencionalmente, dessa rede autopoiética de significaçóes chamada por Flusser de língua (e realidade).

Embora a filosofia flusseriana do período brasileiro se desenvolva por muitos caminhos, nosso enfoque, para este artigo, será sua tese inaugural - a qual constitui a semente de grande parte de suas ideias posteriores - de que "a língua, isto é, o conjunto dos sistemas de símbolos, é igual à totalidade daquilo que é apreendido e compreendido, isto é, a totalidade da realidade." (FLUSSER, 2007, p. 201). Flusser assume que essa proposição é tautológica, porque define a língua como conjunto de símbolos e o apreensível-compreensível como realidade. ${ }^{3}$ É logicamente dedutível dessas definiçôes que, se símbolos e apenas símbolos podem ser apreendidos e compreendidos, língua é o mesmo que realidade (dadas as definiçóes anteriores). Entretanto, não importa o vazio lógico da ontologia flusseriana, mas a imensa arquitetônica que pode ser fundada sobre o fértil alicerce de que o indizível é nada e de que o real é dizível, seja através de balbucios e repetiçôes, seja através de diálogos e de arte. Esse esquema se mantém como pano de fundo em todas as fases de seu pensamento - embora o autor se assuma biograficamente como Bodenlos (sem chão, solo, fundamento): devido ao desenraizamento em relação à sua cultura materna, sua filosofia fundamenta-se em um solo relativamente consistente.

A primeira premissa da filosofia de Flusser assemelha-se à contraposição tipicamente grega entre as aparências e a realidade. No entanto, con-

\footnotetext{
${ }^{3}$ Flusser é consciente de que sua tese ontológica é uma proposição lógica simples de identidade: $\mathrm{A}=$ conjunto de símbolos; $\mathrm{B}=$ o que é apreensível e/ou compreensível; língua $=\mathrm{A}$; realidade $=\mathrm{B}$. Se $\mathrm{A}=$ $\mathrm{B}$, língua é igual realidade. Todavia, constitui uma identidade nâo apenas pouco óbvia, como muito contestada, a qual usa termos complexos amplamente desenvolvidos pelo autor. Portanto, náo se trata de uma tautologia frívola.
} 
trariamente à tendência grega, as aparências caóticas são pensadas pelo autor como algo a que não temos acesso, pois nossos modos de acesso já são modos de ordenação, ou seja, de fixação das aparências dentro de alguma estrutura e de coordenação entre elas, através de algum sistema de regras. Nesse sentido, as aparências não são reais, pois não podem ser experimentadas. A realidade é o esquema em que se dá a experiência humana do mundo. Logo, aquilo que circunda os animais ou as plantas não é realidade, para eles; a rigor, só o ser humano tem realidade, porque ela é composta pelas estruturaçóes ordenadoras que possibilitam a apreensão e a compreensão das aparências ou fenômenos desordenados. Real, por conseguinte, é aquilo que se realiza, em um sentido mais próximo da utilização anglofônica do verbo: "do you realize it?", isto é, "você percebe?", "você compreende?" Algo se torna real, porque se realiza, porque passa a ser apreendido pelos intelectos que participam da realidade: "A filosofia, a religião, a ciência e a arte são os métodos pelos quais o espírito tenta penetrar através das aparências até a realidade e descobrir a verdade. O esforço abrange, portanto, todo o território da civilização humana." (FLUSSER, 2007, p. 32). É claro que filosofia e ciência são métodos característicos da nossa cultura, os quais não abrangem, portanto, todo o território da civilização humana. As outras civilizaçóes, no entanto, estâo sempre empenhadas no mesmo processo de "realização", ainda que o arquitetem de formas diferentes.

Esse tipo de ontologia estabelece uma atenuação dos conceitos de "verdade", "realidade" e "conhecimento", pois exige a conscientizaçấo de que eles dizem respeito a algum modo de estruturação cultural, e não ao mundo tal como ele seria, independentemente do intelecto humano. Isso não significa que não existem conhecimento, realidade e verdade, mas que eles não são absolutos e imediatos. A lógica, a matemática e a ciência continuam válidas, porém, de uma maneira mais modesta: não valem para uma suposta realidade em si, mas para certo tipo de realidade que, por acaso, dentre todas as possibilidades de ordenação, tornou-se a nossa. De acordo com Flusser, a cultura ocidental levou alguns séculos para intuir que a religiấo e a filosofia não eram verdades fundamentais, mas modelos de compreensão do cosmos, e que outros modelos podiam existir, que diferentes religiôes e diferentes filosofias podiam coexistir, sem que houvesse algum critério extrarreligioso ou extrafilosófico que garantisse qual delas é mais verdadeira. $\mathrm{O}$ mesmo processo deve acontecer com a ciência e a matemática, as quais ainda conservam, atualmente, o estatuto de conhecimento e de verdade oficial que a religião cristã mantinha na Idade Média. O pensamento de Flusser não é cético, nem niilista, entretanto, 
defende uma relativização da realidade que não costumava ser admitida pela rigidez dos sistemas ontológicos tradicionais.

A realidade é relativa, porque é identificada com a língua. Essa afirmação continua a chocar o ouvido contemporâneo, embora não tenha nada de original, porque já era declarada pelas antigas sabedorias: os nomes tinham poderes mágicos reais para os povos primitivos: logos é o fundamento do mundo para os gregos pré-socráticos, nama-rupa, a palavra-forma, também o é para os hindus pré-vedistas, assim como hacadoch, o nome santo, para os judeus, e o Verbo para o evangelho cristão. A concepção de língua adotada por Flusser abrange essas sabedorias, bem como as contribuiçóes da ciência linguística, da matemática pura, da poesia, e vai além de tudo isso. Se, por um lado, ele utiliza os conhecimentos da história, da filosofia, da ciência e da experiência pessoal de um poliglota exilado, por outro lado, ele adota a epoché fenomenológica como método para abordar a língua como que "à primeira vista”, suspendendo os conhecimentos acumulados a seu respeito, para poder atingir seu cerne, seu eidos. Isso não significa que Flusser procura uma definição de "língua", o que ele considera uma "tentativa frustrada pela própria posição ontologicamente primordial” (FLUSSER, 2007, p. 35) que concede ao conceito. Ademais, o preço do estabelecimento de uma definição costuma ser a improdutividade, a estagnação do diálogo. A fixação de um conceito concebido como correto e verdadeiro é uma forma de cristalizar as informaçôes, de arrefecer as tentativas de compreensão e as discussóes a respeito do tema. Como no pensamento flusseriano, a arte é o princípio ontológico que se contrapóe à estagnação, à fixação e à cristalização da língua, visto que cada palavra é uma espécie de obra de arte colocada na realidade. A própria língua é uma obra de arte coletiva, constituída por incontáveis geraçóes de intelectos que colaboraram conjuntamente para sua produção e significância:

Ela encerra em si toda a sabedoria da raça humana. Ela nos liga aos nossos próximos e, através das idades, aos nossos antepassados. Ela é, a um tempo, a mais antiga e a mais recente obra de arte, obra de arte majestosamente bela, porém sempre imperfeita. E cada um de nós pode trabalhar essa obra, contribuindo, embora modestamente, para aperfeiçoar-lhe a beleza. [...] Graças a este nosso trabalho ela continuará enriquecida em seu avanço. Já agora, nesta introdução, aventuro-me a sugerir que se resume a isto nosso papel na estrutura do cosmos. Mas, pensando bem, formulando e articulando, não estamos sendo homens no sentido mais digno dessa palavra? Não estamos, com essa atividade, preenchendo e, talvez, ultrapassando a condição humana? (FLUSSER, 2007, p. 37). 
Essa bela caracterização flusseriana da língua como uma imensa obra de arte coletiva explica que língua, realidade, arte e humanidade são tratadas como concepçôes primordiais e inseparáveis. Assim como os grandes pensadores antigos, Flusser cria, em certo sentido, um amálgama entre estética, ontologia e ética: o ser ou a realidade é a língua, que é uma criação humana, portanto, uma obra de arte majestosamente bela (poderíamos acrescentar: por vezes, também deplorável, ideológica, violenta e amesquinhadora), e participar desse trabalho resume a dignidade (ou indignidade) humana.

Assim, é preciso investigar com mais profundidade a ideia de que a realidade é linguística. Como seria possível resumir à língua os dados percebidos com os sentidos? Flusser assume que os doadores imediatos de dados são os sentidos, todavia, defende que esses dados, a princípio caóticos ou inarticulados, só alcançam o intelecto em forma de língua. Nesse ponto, Flusser lança mão da diferença entre um sensu lato e um sensu stricto de intelecto. Estritamente falando, o intelecto é a articulação de palavras e frases, ou, para usar uma expressão de $A$ dúvida, outro livro do período brasileiro, escrito no início da década de sessenta, é "o campo onde ocorrem organizaçôes linguísticas." (FLUSSER, 2011, p. 51). Contudo, em sentido amplo, o intelecto tem uma "antessala" que computa os dados sensíveis brutos, articulando-os como palavras. Essa antessala é um estado intermediário entre os sentidos e o intelecto estrito, no entanto, assim que a penetram, os dados brutos já iniciaram o processo de transformação em língua por isso Flusser os denomina "palavras in statu nascendi" e afirma que a realidade consiste de palavras e de palavras in statu nascendi. Ou seja, não é possível conhecer o dado bruto puro ou o caos de percepçôes sensíveis inarticuladas, aliás, esses conceitos filosóficos são abstrações bastante tardias. Não é possível ver formas puras, nem tocar a textura pura. Os seres humanos enxergam e tocam as coisas, quando elas passam a adquirir significado, pois ver e tocar já são modos de gerar significado - são nossos modos de apreender as coisas. Quando escutamos um idioma que ignoramos, não escutamos ruídos puros; escutamos palavras desconhecidas. Toda percepção sensível acontece em um âmbito de significados, que é língua ou língua nascente. Mesmo quando percebemos algo para o qual ainda não dispomos de nomes, há indexadores da língua capazes de lidar com o dado ignoto (mas linguístico!) como "isso", "aquilo", "algo".

Flusser está defendendo, em última instância, que não há outra fonte de significação além da linguagem. As palavras são símbolos significativos, logo, apontam para algo, mas não para a realidade ingênua dos realistas. Se as palavras "procuram algo além da língua, não é possível falar-se desse algo" 
(FLUSSER, 2011, p. 41), que deve ser considerado, portanto, irreal ou pré-real. ${ }^{4} \mathrm{~A}$ relação entre a frase "o gato pulou" e o gato que vemos pulando não é uma relação entre uma frase e um dado sensível, porém, uma relação entre duas frases, estando a primeira em forma de língua enunciativa e a segunda em forma do que poderíamos chamar de "língua perceptiva". Essa expressão pode soar contraintuitiva, mas faz sentido na teoria flusseriana, porque as coisas percebidas são o lado sensível das palavras. Detecto, nesse ponto, uma subversão da tradicional metafísica realista, a qual concebe as palavras como correlatos significativos (símbolos) das coisas reais, entendidas como substâncias independentes da língua. Flusser subverte esse esquema, ao afirmar que não há coisas reais prévias à língua. Porém, não o inverte, porque não concebe as palavras como anteriores e independentes das coisas reais. Língua e realidade formam-se simultaneamente, como os dois lados de uma moeda.

Há uma reflexão de Flusser sobre a "língua ampliada" que ajuda a esclarecer em que sentido as coisas reais são o lado sensível da língua: a língua em sentido estrito é um conjunto de significados que são percebidos sensorialmente como signos visuais e auditivos; a língua em sentido ampliado inclui símbolos que são exteriorizações do aspecto visual/plástico ou do aspecto auditivo da língua, como a música e as artes plásticas. Assim como a música é língua, pois é exteriorização (rumo aos sentidos) do aspecto auditivo da língua, as artes plásticas e toda a "civilizaçấo material”, a qual inclui "a arquitetura, os instrumentos de uso diário e os implementos” (FLUSSER, 2007, p. 178), são língua, pois são exteriorização do aspecto visual ou plástico da língua. Assim, as coisas da civilizaçáo material, produzidas pelo ser humano, são o lado plástico da língua. As coisas naturais, embora conservem a ilusão de ser algo anterior ao intelecto, também existem somente na medida em que são concebidas linguisticamente: "Aquilo que chamamos de coisas naturais, as pedras, as estrelas, a chuva, as árvores, a fome, são fenômenos reais, porque são conceitos, palavras. As relaçôes entre os fenômenos são reais, porque formam pensamentos, frases.” (FLUSSER, 2007, p. 190). Dessa maneira, aquilo que a ciência do XVIII "descobria” como leis necessárias da natureza são simplesmente leis contingentes (mas não menos persuasivas) das línguas flexionais, por-

\footnotetext{
${ }^{4}$ Se há algo anterior à língua, não podemos considerá-lo real, porque não é apreensível para nós. Logo, seria real para quem? Para náo margear um idealismo berkeleyniano, Flusser delimita o conceito de real ao âmbito do que podemos apreender. E todas as formas de apreender são "língua" em sentido amplo, na ontologia flusseriana. Isso evidentemente não significa que não existam coisas que não têm nomes, pois estas são cingidas linguisticamente por indicadores formais, como "isso" e "aquilo". Também não significa que não existam nomes que não tenham um correlato sensível, porque palavras como "pégaso", que geraram tanta disputa entre os filósofos da linguagem, correspondem a uma realidade não-sensível, isto é, a um grupo de imagens, a um acervo discursivo de seres mitológicos, a contos etc.
} 
que os fenômenos em geral satisfazem as regras da língua em que são estabelecidos. Com efeito, a ciência contemporânea, como a física quântica, depara-se cada vez mais com o reconhecimento de que a natureza e suas leis são perspectivas linguísticas e de que a verdade tem mais a ver com o poder explicativo e/ou pragmático de certas formulaçóes do que com a adequação de leis naturais à natureza. $\mathrm{O}$ ilustre problema da verdade como adaequatio rei et intellectus, na metafísica, que conduz à dúvida cartesiana sobre como saber se os nossos pensamentos se adéquam às coisas tal como elas são em si mesmas, só faz sentido porque essa metafísica pressupôs de maneira inquestionável a cisão entre res cogitans e res extensa, como se fossem duas substâncias independentes. Se a língua/pensamento e a realidade/extensão são o mesmo, elas não podem não se adequar, e o problema da verdade é simplificado à "correspondência entre frases ou pensamentos, resultando das regras da língua." (FLUSSER, 2007, p. 46).

Assim, o dado bruto é realidade in statu nascendi, porque é palavra in statu nascendi, e antes disso não é: não é acessível, dizível, perceptível, significante. Na medida em que os dados brutos vão sendo conversados, tornam-se cada vez mais abstratos, isto é, deixam de ser palavras brutas e passam a ser palavras cheias de significados, atribuídos pelas inúmeras predicações a que estão associados. Podemos argumentar que a realidade flusseriana é simbólica e que os símbolos são formados pelas atividades linguísticas de nomear e conversar. ${ }^{5}$ As coisas percebidas cotidianamente são símbolos, a natureza é símbolo, as palavras são símbolos e os dados brutos são símbolos precários, pois são "recém-nascidos” e ainda estão muito próximos do não-real ou não-simbólico, do qual nada podemos falar. Para adotar uma preferência um tanto pós-histórica do próprio Flusser por diagramas, pode-se esquematizar o núcleo de sua ontologia do seguinte modo:

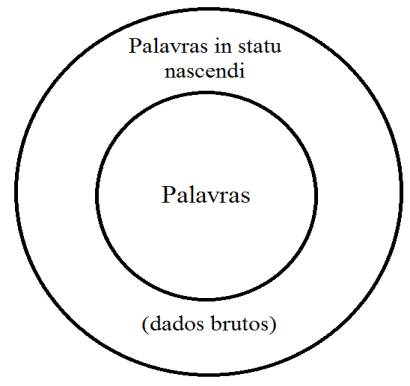

\footnotetext{
5 Com essa explicação, as atividades de nomear e conversar têm que ser expandidas para a língua ampliada, a qual inclui a música e as artes plásticas, por exemplo. Compor uma música seria um ato de nomear tanto quanto criar um conceito.
} 
Na figura acima, a realidade é delimitada pelo que está dentro do círculo. Bem entendido, "palavras" têm sentido ampliado nesse contexto, que engloba imagens, sons, coisas naturais e construídas etc. $\mathrm{O}$ que está fora do círculo é nada, no sentido de que não pode ser apreendido e compreendido, logo, não é real para nós. Se algo de fora do círculo é apreendido, é porque entrou no processo de tornar-se palavra, logo, já está dentro do círculo da realidade, mesmo que muito próximo da periferia. A ontologia de Flusser deve ser pensada como dinâmica e gradativa. Não se trata de uma oposição extrema entre ser e não-ser, todavia, de um "sendo", de um vir-a-ser, o qual consiste na constante criação e expansão da língua. A figura acima não deve ser imaginada como uma fronteira sólida e finalizada entre real e não-real, mas como um processo de realização: a periferia é extremamente porosa e absorvente, o centro é mais sólido, e entre um e outro há um movimento de solidificação (o qual, surpreendentemente, Flusser chama de abstração - cf. Flusser (2002, p. 147-148) que se dá através da conversação. Os conceitos flusserianos em geral sofrem transiçóes gradativas: da pré-história para a história e desta para a pós-história, do nada para o dado bruto e deste para as palavras, dos nomes primários aos secundários, do concreto ao abstrato. A língua, a realidade, o intelecto, as estruturas culturais não surgem do nada, repentinamente: formam-se aos poucos e de modo contínuo. Por isso, há vários níveis de intelecto e de língua, desde o balbucio até a oração, que coexistem tanto quanto as existências históricas, pré-históricas e pós-históricas - assuntos importantes e amplamente conhecidos pelos estudiosos de Flusser, que são desenvolvidos na fase europeia de sua filosofia -, e tanto quanto a realidade solidificada de uma árvore e a realidade ainda precária de um pósitron.

O nada ou o caos que circunda a realidade não é o absolutamente vazio, mas a potencialidade de gerar língua. "Nada" é por definição um conceito radicalmente externo à realidade, logo, é o não-tornado-língua, o indizível. Entretanto, indizível apenas porque ainda náo dito. Trata-se simplesmente do inarticulado, a partir do qual todos os níveis de articulaçáo linguística se estabelecem. Assim, o nada é fonte da realidade, do vir-a-ser, mas é o limite da língua e do intelecto - não podemos articular o não-real, sob pena de torná-lo real, e náo podemos compreendê-lo (a não ser alegoricamente ou por contraposição, como o não-real, não-articulado, não-dizível, não-compreensível). Flusser (2007, p. 132) resume sua posição, afirmando que "a grande conversação que somos surge do indizível e trata do indizível”, pois o intelecto não pode evitar a tentativa de articular sua origem. Contudo, em meio a essas reflexôes, encontra-se a chocante afirmação de que "o $E u$ e o Não-eu são as 
duas faces daquele nada que, de acordo com o pensamento existencial, estabelece (herstellt) o Ser." (FLUSSER, 2007, p. 131). Trata-se de uma declaração espantosa, porque, como o indizivel pode ser dito como tendo duas faces? Assinalei anteriormente que, na ontologia flusseriana, a língua forma intelecto e realidade ao mesmo tempo. Com efeito, o filósofo analisa o surgimento do intelecto e o surgimento da objetividade como língua percebida internamente e língua percebida externamente. Pode-se esquematizar esses conceitos da seguinte forma:

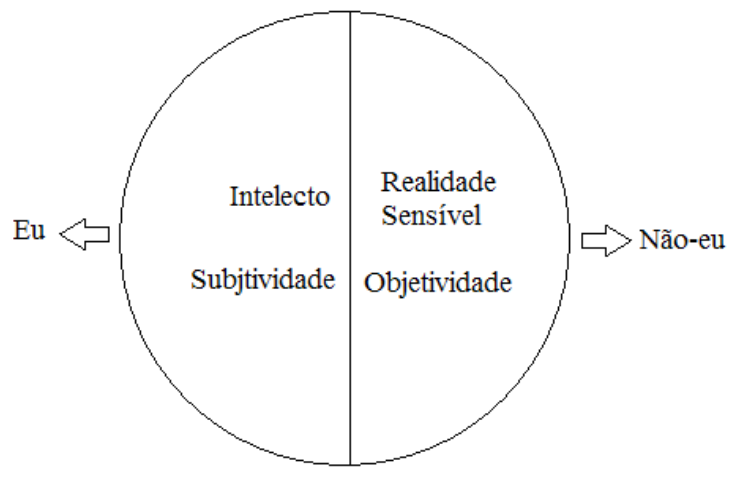

Na figura acima, o círculo representa a língua e o que está fora dele é nada, é indizível. Mas como dividi-lo em duas categorias? A cisão na língua entre intelecto e realidade objetiva já é perturbadora, pois há teorias as quais argumentam, por exemplo, que crianças pequenas e civilizaçóes organizadas por um pensamento mágico náo distinguem entre um dentro e um fora, isto é, não vivem através de uma ruptura entre subjetividade e objetividade. Então, como usar essa distinção histórica, característica da razão esclarecida, como distinção ontológica presente até mesmo no indizível? Para resgatar Flusser desse mal-entendido, proponho que essa distinção não é uma necessidade $a$ priori em sua teoria: a história das línguas flexionais conduziu-se de tal maneira que subjetividade e objetividade foram separadas, tal como o sujeito e o objeto das frases, e por isso podemos perceber a língua internamente, como intelecto, e externamente, como realidade sensível. O que há, no entanto, é língua - intelecto, realidade, subjetividade e objetividade são modelos desenvolvidos historicamente em seu processo de concretização. Ou seja, em última instância, a única cisão que funciona como princípio ontológico para Flusser é a dualidade, dificilmente contestável, entre articulado e não-articulado. Assim, a passagem citada acima precisa ser compreendida do seguinte modo: 
ao buscar suas origens, o pensamento-língua tenta dizer o indizível e, como é inconsciente de que língua é realidade (logo, de que ele é autopoiético), acaba projetando a distinção entre intelecto e objetividade para o indizível, chamando-o ora de Eu, Espírito, Deus, ora de Não-eu, coisa-em-si, mundo. Nessa interpretação, Flusser não estaria defendendo uma distinção ontológica no indizível, mas explicando a origem da metafísica como tentativa de dar nome ao inarticulado.

O pensador não defende um dualismo no indizível, uma vez que, para além ou aquém da linguagem, não se pode dizer como as coisas são, nem que elas são. Como declararia Parmênides, "o não ente não pode ser dito" - o que também poderia significar que o não dito não pode ser ente. Flusser admite, em várias passagens, que é impossível falar sobre o que ultrapassa as raias da língua, a não ser alegoricamente. Todavia, ele inicia Lingua e realidade explicando que o espírito humano cria a língua, porque não suporta um mundo caótico: "O espírito, em sua 'vontade de poder', recusa-se a aceitá-lo. [...] Uma das ânsias fundamentais do espírito humano em sua tentativa de compreender, governar e modificar o mundo é descobrir uma ordem." (FLUSSER, 2007, p. 31). Ou seja, o ser humano é dotado de vontade que se contrapõe à incompreensibilidade e à falta de significação do caos, e dotado de uma forma de superá-las, a saber, a criação da língua que ordena o caos em cosmos. Note-se que esse é um pressuposto claramente nietzschiano e schopenhaueriano, no alicerce da identificação entre língua e realidade. A vontade estaria no fundo da ontologia flusseriana? Ela pode ser compreendida como algo próximo da vontade de poder nietzschiana, com a ressalva de que é pensada no registro linguístico? Em $A$ história do diabo, livro que também foi escrito e publicado no Brasil, em 1965, o autor descreve a vontade como algo que "pressiona. Quer explodir. É sedenta. Quer espalhar-se. Está em tensão. Procura sair de si mesma. Quer projetar-se. Procura poder. Quer realizar-se.” (FLUSSER, 2008a, p. 160). Trata-se de uma caracterização muito próxima da noçáo nietzschiana de vontade de poder. Flusser assevera, ainda, que tudo que é, foi, será e pode vir a ser é a própria vontade. Ou seja, o mundo está aqui, diante de nós, porque fizemos com que ele surgisse do abismo do nada. A vontade humana é o princípio e o fim do cosmos; ela cria o mundo e depois interessa-se por conhecer sua obra, descobrindo, por fim, a si mesma no fundo do mundo. Ela também cria o intelecto e depois o analisa, descobrindo a si mesma no fundo do intelecto. Por conseguinte, mundo e Eu são duas faces da vontade, são, na verdade, os mais espessos véus que a encobrem. Natureza e mente são obras da vontade, 
embora mantenham a ilusão de autonomia - são, em última análise, obras de arte, criaçôes humanas, assim como a própria língua.

Ainda nesse livro, Flusser descreve a identificação ontológica entre língua e realidade com uma bela alegoria: imagina que a vontade é uma aranha que secreta, como teia, a língua-realidade. Os fios são as frases e os nós que os ligam são amarrados pela ilusão do princípio de individualização (uma óbvia releitura do principium individuationis descrito por Nietzsche, em sua teoria da tragédia), formando os intelectos. A teia cresce e os fios, alimentados continuamente pela vontade, tornam-se cada vez mais resistentes, surgem novas ramificaçóes, novas interligaçóes entre fios e intelectos. As pontas de alguns fios ainda não muito consolidadas, flutuam no vácuo. Eles são tecidos pela vontade através de alguns intelectos nos quais ela pulsa com mais intensidade, procurando expandir a teia. Esses intelectos encontram-se em uma situação arriscada e extrema, porque estão em contato com o nada e pressentem, de algum modo, que a teia é obra da vontade e paira sobre o vazio. Eles funcionam como órgãos de secreção da vontade, a partir de onde ela cria novos fios, isto é, discursos, fatos, obras, ideias, imagens, conceitos; em suma, esses intelectos, que o autor chama de "poetas", são a fonte da língua. Expostos arriscadamente ao nada, mas ainda presos pelos fios da língua, eles produzem obras que são testemunhas de seu contato dilacerador com o nada, mas são também a exaltação do poder da vontade - são, portanto, um tipo de soberba.

Assim como Schopenhauer e Nietzsche, Flusser pressupóe que a vontade é o que há de mais concreto. As novas ideias, criadas por aqueles intelectos que funcionam como uma espécie de vanguarda da vontade, são o que está mais próximo de sua concretude. Elas são assimiladas aos poucos pela teia da realidade, na medida em que são compreendidas e conversadas. Tornam-se, por conseguinte, mais abstratas, pois se afastam do concreto, e são progressivamente apropriadas como verdades, como fenômenos independentes, cuja origem na atividade criadora da vontade é obliterada. No centro da teia, em suas partes mais cristalizadas, estão os conceitos fixos que sustentam a cultura ocidental, e todos eles são assimilados dentro do modelo dualista mente-natureza. O chamado "mundo fenomênico" é justamente essa região tão assegurada e saturada de conceitos que quase náo pode ser percebida como dependente da vontade humana. Assim, obras que, em algum momento, a vontade criou são incorporadas como fenômenos autônomos da natureza ou da mente. Trata-se de uma tendência rumo à abstração da língua, isto é, rumo à cristalização dos pensamentos ou frases criados pela vontade humana. Alguns, como, por 
exemplo, os pensamentos elaborados por cientistas, transformam-se rapidamente em fenômenos naturais, cuja existência passa a ser compreendida como necessária e independente. Outros demoram um pouco mais para ser abstraídos, como, por exemplo, as obras de arte. A música, a pintura e a poesia são tipos de pensamentos criados pela vontade, os quais resistem a serem transformados em "dados" pela nossa cultura.

Os assuntos abordados até aqui, obviamente, são apenas uma pequena parte do pensamento flusseriano desenvolvido em solo brasileiro. Menos do que isso, são uma pesquisa que se concentra em parte de seu primeiro livro publicado, Lingua e realidade, o qual aborda muitos outros temas, como a descrição de diferentes troncos linguísticos, a possibilidade e as dificuldades de tradução, os diferentes níveis da língua (balbucio, salada de palavras, conversa fiada, conversação, poesia e oração), a arte, compreendida como poiesis, e assim por diante. Concentrei-me na tese central do livro, de que a língua e a realidade são o mesmo, ou melhor, de que as diversas línguas se identificam com as diversas realidades, porque defendo a hipótese de que essa tese inaugural fundamenta as principais ideias que o autor desenvolve, posteriormente - mesmo quando se torna um renomado teórico dos media, da comunicação, da fotografia, do design etc. Isso significa que a fase europeia e mais conhecida da sua obra se baseia em ideias originais, até mesmo radicais, as quais foram elaboradas na fase brasileira e bem menos conhecida de seu pensamento.

Flusser deixou o Brasil em 1972, trinta e um anos depois que chegou, fugindo da perseguição nazista, e 22 anos após ter-se naturalizado brasileiro, para viver inicialmente na Itália e, depois, na França e na Alemanha. Em meados da década de 70, passou a ocupar-se mais especificamente das situaçôes provocadas pelo desenvolvimento dos capitalismos avançados, como o crescimento da cultura de massas, a crise da ciência e a autoridade inexorável das tecnologias de ponta, como a telemática e a microeletrônica. Com essas novas preocupaçóes, sem dúvida influenciadas pelo retorno ao solo europeu, o pensador tcheco prepara, de acordo com Rodrigo Duarte (2011, p. 10-11), um projeto de compreensão ampla de todos os sintomas da situação atual, sob o denominador comum "sociedade pós-industrial", a qual também poderia ser chamada de "sociedade pós-Auschwitz". Nessa época, quando retorna à Europa, em 1972, Flusser escreve A fenomenologia do brasileiro, obra editada originalmente em alemão, com o título de Brasil, ou a procura de um novo homem: por uma fenomenologia do subdesenvolvimento (Brasilien oder nach dem neuen Menschen: Für eine Phänomenologie der Unterentwicklung), 
publicada apenas em 1994. Pode parecer estranho que um artigo nomeado "Vilém Flusser, um filósofo da linguagem brasileiro" não se concentre especificamente nessa obra. Não obstante, é justamente porque procuro capturar o pensamento brasileiro de Flusser, e não seu pensamento sobre o Brasil, que investigo, aqui, suas primeiras obras, em vez de sua descrição fenomenológica tardia - e em alguns aspectos bastante estrangeira - da nossa cultura.

A originalidade das ideias de Flusser relaciona-se intimamente com as condiçôes em que foram criadas, isto é, com sua ausência de formação universitária e com o afastamento em relação às principais discussóes da filosofia europeia, na época. Isso permitiu que seu pensamento se desenvolvesse de uma forma bastante livre, individual, heterogênea e múltipla, em diálogo com outras áreas e com importantes intelectuais e artistas brasileiros. Espero que, com esses breves apontamentos acerca de alguns aspectos da filosofia flusseriana, se possa observar que ela é, desde o início, extremamente criativa e vasta. Flusser foi acolhido como um intelectual de referência na Europa, antes sê-lo no Brasil, e, embora nos últimos anos seu pensamento venha sendo cada vez mais respeitado pelos pesquisadores brasileiros, a fase europeia de sua filosofia continua em destaque. Atentar para o período no qual o autor desenvolveu uma filosofia da linguagem bastante original, no contexto do nosso país, é relevante não apenas porque impulsiona o escasso estudo da cultura filosófica brasileira, mas também porque oferece outro ângulo para aprofundar a leitura a respeito de um intelectual táo singular.

FERREIRA, D. P. Vilém Flusser, a Brazilian philosopher of language. Trans/formlação, Marília, v. 41, n. 2, p. 37-54, Abr./Jun., 2018.

ABSTRACT: The purpose of this paper is to contribute to the knowledge and recognition of Brazilian philosophy by presenting some aspects of the theory of one of our most original authors, Vilém Flusser. Of Czech and Jewish origins, Flusser was naturalized as a Brazilian and lived for over thirty years in Sáo Paulo. During this period, he wrote an important but little-studied part of his work. This paper analyses certain aspects of Flusser's ontology which characterize his experience on Brazilian intellectual ground. The paper focuses on his thesis that language and reality are the same, or rather, that the various languages can be identified with various realities. This idea was defended in Flusser's first book, Lingua e realidade (Language and Reality), which was published in 1963.

KeYwords: Brazilian philosophy. Language. Reality. Ontology. 


\section{REFERÊNCIAS}

BATLICKOVA, E. A época brasileira de Vilém Flusser. Sáo Paulo: Annablume, 2010.

DUARTE, R. A. P. Prefácio. In: Pós-história - vinte instantâneos e um modo de usar. São Paulo: Annablume, 2011.

. Pós-história de Vilém Flusser: gênese, autonomia, desdobramentos. São Paulo:

Annablume, 2014.

FLUSSER, V. Ensino estético. [s.l.: s.n], 1989. Manuscrito disponível no Arquivo Flusser. . Fenomenologia do brasileiro. Rio de Janeiro: EDUERJ, 1998.

. Lingua e realidade. 3. ed. São Paulo: Annablume, 2007. . A história do diabo. São Paulo: Annablume, 2008a.

. O universo das imagens técnicas: elogio da superficialidade. São Paulo:

Annablume, 2008b. . A escrita: há futuro para a escrita? São Paulo: Annablume, 2010. . A dúvida. São Paulo: Annablume, 2011 a. . Filosofia da caixa preta. Sáo Paulo: Annablume, 2011b. . Pós-história - vinte instantâneos e um modo de usar. São Paulo:

Annablume, 2011c. .; BEC, L. Vampyroteuthis infernalis. São Paulo: Annablume, 2011.

KRAUSE, G. B.; GULDIN, R.; FINGER, A. Vilém Flusser: uma introdução. São Paulo: SP: Annablume, 2008.

KRAUSE, G. B.; MENDES, R. (Org.). Vilém Flusser no Brasil. Rio de Janeiro: Relume Dumará, 2000.

MARTINS, C. S. Vilém Flusser: a tradução na sociedade pós-histórica. São Paulo: Humanitas, 2011.

PARMÊNIDES, citaçóes de Clemente de Alexandria e Proclo. In: Pré-socráticos. São Paulo: Nova Cultural, 1999. (Os Pensadores).

Recebido: 20/03/2016 Aprovado: 08/05/2017 
FERREIRA, D. P 